UDC $577.22+577.181 .5$

\title{
Mitochondria do not play a major role in landomycin E-induced ROS burst and circumvention of multiple drug resistance in HL-60 leukemia cells
}

\author{
R. R. Panchuk ${ }^{1}$, L. V. Lehka ${ }^{1}$, J. Rohr ${ }^{2}$, W. Berger ${ }^{3}$, R. S. Stoika ${ }^{1}$ \\ ${ }^{1}$ Institute of Cell Biology NAS of Ukraine \\ 14/16, Drahomanov St., Lviv, Ukraine, 79005 \\ 2 University of Kentucky, College of Pharmacy, Lexington, USA, \\ 789 S. Limestone St. Lexington \\ ${ }^{3}$ Institute of Cancer Research and Comprehensive Cancer Center, Medical University Vienna, \\ 8a, Borschkegasse, Vienna 1090, Austria \\ rpanchuk@ukr.net
}

\begin{abstract}
Aim. To study the molecular mechanisms of reactive oxygen species (ROS) involvement in circumventing the cancer drug resistance by novel angucycline antibiotic landomycin E in HL-60 human leukemia cells and its drug-resistant sublines HL-60/adr and HL-60/vinc. Methods. MTT assay, trypan blue exclusion test, DCFDA and JC-1 staining of cells. Results. Landomycin E (LE) leads to a massive hydrogen peroxide production in HL-60 cell line already $1 \mathrm{~h}$ after the drug addition to the cell culture, while depolarization of mitochondria is observed only at 6-12h, which indicates on the extra-mitochondrial ROS production by LE. The drug-resistant cells of HL-60/vinc (P-gp+) despite 100-fold resistance to doxorubicin (Dx) action, demonstrated no difference in the resistance to LE compared to the parental cell line, while HL-60/adr line (MRP-1+), which was found to be 200-fold resistant to Dx action, had shown a weak (2-fold) decrease in sensitivity to LE. Circumvention of drug resistance by LE in HL-60/adr cells was accompanied by a 2-fold higher level of $\mathrm{H}_{2} \mathrm{O}_{2}$ compared to the wild-type cells, but the mitochondrial respiratory chain inhibitors had no impact on this phenomenon. Conclusions. LE-induced cell death is accompanied by massive hydrogen peroxide production, consisting of two peaks - major one at $1 \mathrm{~h}$ and secondary at $12 \mathrm{~h}$ after drug treatment. The highest ROS production was observed in HL-60/adr cells, which have shown a 2-fold increase of resistance to LE compared to parental cells. However, mitochondria seem to play secondary role in this process, due to the fact that use of specific inhibitors of mitochondrial respiratory chain did not affect the early ROS burst, induced by LE in tumor cells.
\end{abstract}

Ke y w o r d s: landomycin E, ROS, mitochondria, cancer drug resistance, apoptosis

\section{Introduction}

Despite advancement of modern pharmacology in the development of efficient anticancer drugs, the overall ratio of successful results of the metastatic cancer chemotherapy still remains rather low. Compared to the golden chemotherapy standards (anthracyclines and vinca alkaloids), developed in early 1960s, over the last decade the specificity of modern targeted medi- cines became markedly higher and their side effects significantly diminished. However, the average survival time of patients with disseminated cancer did not considerably increase] [1].

Such ineffectiveness of cancer chemotherapy is explained by the rapid development of acquired multi-drug resistance (MDR) of tumor cells to the anticancer drugs, which is found in $30-50 \%$ of cancer patients already in a year after the treatment

(C) 2016 R. R. Panchuk et al.; Published by the Institute of Molecular Biology and Genetics, NAS of Ukraine on behalf of Biopolymers and Cell. This is an Open Access article distributed under the terms of the Creative Commons Attribution License (http://creativecommons.org/licenses/by/4.0/), which permits unrestricted reuse, distribution, and reproduction in any medium, provided the original work is properly cited 
start [2]. The MDR phenotype is characterized by the simultaneous resistance of cancer cells to the pharmacologically and structurally diverse drugs [3]. It could be a cause of the poor prognosis and lower survival rate in several types of cancer such as gastric cancer, breast cancer, ovarian cancer, pancreatic cancer, and leukemia $[4,5]$

MDR is related to an increased production of the ATP-Binding Cassette (ABC) transport proteins. the membrane-bound proteins that extrude a variety of anticancer drugs from the tumor cells using ATP hydrolysis. Until now, 48 human ABC genes have been identified and classified into seven subfamilies based on the sequence homology and domain structure [1]. In addition to their physiological expression in normal tissues, these proteins were found to be over-expressed in the human tumors, which significantly lowers their response to the chemotherapy treatment. Although all types of $\mathrm{ABC}$ transporters are involved in drug resistance, most studies on the $\mathrm{ABC}$ transporter protein in cancer have focused on three proteins: P-gp (p-glycoprotein), MRP-1 (multidrug-resistance associated protein), and BCRP (breast cancer resistance protein). Each of the above drug transporters is specific to a certain type of substrates. In particular, $\mathrm{P}$-glycoprotein is responsible for resistance to colchicine, dexamethasone, doxorubicin, vinblastine, and etoposide, whereas the over-expression of MRP-1 protein results in resistance to vincristine and doxorubicin[6, 7]. In turn, bcrp, besides resistance to methotrexate and mitoxantrone, is also responsible for the cancer cell resistance to targeted chemotherapies, such as imatinib and lapatinib, which makes it especially important in modern cancer chemotherapy [8].

Thus, the development of novel anticancer drugs, capable of circumventing the cancer drug resistance in different ways, which could not be inhibited by any of known drug resistance mechanisms, remains an important task of the current pharmacology and medicine. Here, one of promising approaches is searching for natural compounds, the anticancer activities of which could not be affected by the ABC-transporter proteins. Landomycins are a novel group of angucycline antibiotics possessing a strong antineoplastic potential. All natural landomycins identified to date, share the same aglycon (landomycinone) group and vary only in their oligosaccharide chain, a linear glycosidic chain containing only di- and trideoxysugars ( $\beta$-D-olivose and $\alpha$-L-rhodinose [9]. They show a broad activity against many cancer cell lines, with the general tendency that the compounds with longer saccharide chains possess a higher antitumor potential $[10,11]$.

Previously, we studied the cellular and molecular mechanisms of antitumor activity of one landomycin family member - landomycin E, possessing three sugar residues in its saccharide chain. It was shown $[12,13]$ that this drug could overcome the multidrug resistance of cancer cells to chemotherapy treatment due to the over-expression of ABC-transporters. It wasalso shown by us, that the anticancer activity of another member of this family - landomycin A - is accompanied by massive ROS burst at early timepoints of its action, but the molecular mechanisms of this phenomenon still remain unclear [14].

The main aim of the current study was to investigate the ROS profile in HL-60 leukemia cells and the drug-resistant HL-60/adr and HL-60/vinc sublines under LE treatment in vitro, and to evaluate a possible role of mitochondria in circumvention of cancer drug resistance by LE using specific mitochondrial respiratory chain inhibitors. A well-known anticancer drug doxorubicin was used for the comparison .

\section{Materials and Methods}

\section{Materials}

LE-overproducing Streptomyces globisporus 1912 strain was obtained in the laboratory of Prof. B. Matselyukh (D.K. Zabolotny Institute of Microbiology and Virology, National Academy of Sciences of Ukraine, Kyiv). LE (99.5\% purity, according to HPLC data) was prepared in the laboratory of Prof. J. Rohr (University of Kentucky, USA) and dissolved in absolute ethanol to obtain a $4 \mathrm{mg} / \mathrm{ml}$ stock solution. Doxorubicin hydrochloride was obtained from Pfizer (New York, NY). Diphenylene Iodonium (DPI), antimycin A (AMA), oligomycin A (OM), 
$\mathrm{N}$-acetylcysteine (NAC) and sodium pyruvate were purchased from Sigma-Aldrich (St. Louis, MO).

\section{Cell culture and treatments}

Human leukemia cells of HL-60 line, its drug-resistant sublines HL-60/adr (MRP-1 overexpression) and HL60/vinc (P-glycoprotein overexpression) were obtained from the cell culture collections at Vienna Medical University, Institute of Cancer Research, from ATCC. Cells were cultured in RPMI medium, supplemented with $10 \%$ fetal calf serum (Sigma-Aldrich), 50 $\mu \mathrm{g} / \mathrm{ml}$ streptomycin (Sigma-Aldrich), 50 units/ml penicillin (Sigma-Aldrich) in 5\% $\mathrm{CO}_{2}$-containing humidified atmosphere at $37{ }^{\circ} \mathrm{C}$. For experiments[, the] cells were seeded into 24-well tissue culture plates (Greiner Bio-one, Germany). Short-term (24h) cytotoxic effect of antitumor drugs was studied under the Evolution 300 Trino microscope (Delta Optical, Poland) after cell staining with trypan blue dye $(0.1 \%)$.

DPI ( $3 \mathrm{mM}$ stock solution) was dissolved in DMSO, while antimycin A and oligomycin A were dissolved in absolute ethanol to obtain $2 \mathrm{mM}$ stock solutions. NAC $(0.5 \mathrm{M})$ and D-mannitol $(10 \mathrm{M})$ were dissolved in $1 \mathrm{x}$ phosphate buffered saline (PBS). Modulators were added to cell culture $30 \mathrm{~min}$ before addition of anticancer drugs, and final concentration of NAC was $1 \mathrm{mM}$, sodium pyruvate $10 \mathrm{mM}$, DPI and Oligomycin A - $4 \mu \mathrm{M}$. Stock solutions of aforementioned reagents were dissolved in PBS before addition to cell culture.

For long-term (72h) cytotoxicity assays Jurkat cells were plated $\left(5 \times 10^{3}\right)$ in $100 \mu$ per well in 96well plates, and allowed to grow for $24 \mathrm{~h}$. Drugs were added in another $100 \mu$ culture medium (final concentration of DPI $-0.5 \mu \mathrm{M}$, oligomycin A $1 \mu \mathrm{M}$, antimycin $\mathrm{A}-2 \mu \mathrm{M}$, sodium pyruvate $10 \mathrm{mM}, \mathrm{NAC}-1 \mathrm{mM}$ ) and cells were exposed for $72 \mathrm{~h}$. The proportion of viable cells was determined by EZ4U assay according to the manufacturer's recommendations (EZ4U, Biomedica, Vienna, Austria). Cytotoxicity was expressed as $\mathrm{IC}_{50}$ values calculated from full dose-response curves (drug concentration including 50\% reduction in cell survival comparing to the control cultured in parallel without drug).

\section{Flow cytometric assays}

Analyses were performed using a FACScalibur flow cytometer (BD Biosciences, San Jose, CA) and Summit v3.1 software (Cytomation, Inc., Fort Collins, CO). HL-60, HL-60/adr and HL-60/vinc leukemia cells were treated as indicated in the figures.

Cellular ROS contents were measured by incubating the control or drug-treated cells with fluorescent dye dihydrodichlorofluoresceindiacetate $\left(\mathrm{H}_{2} \mathrm{DCFDA}\right.$, $\mathrm{H}_{2} \mathrm{O}_{2}$-specific) in concentration $10 \mu \mathrm{M}$ of $\mathrm{H}_{2}$ DCFDA at $37{ }^{\circ} \mathrm{C}$ for $30 \mathrm{~min}$. After incubation with the fluorochrome, cells were washed with PBS and immediately analyzed at FL1 channel of FACSCalibur flow cytometer (BD Biosciences, San Jose, CA)

Breakdown of $\triangle \Psi \mathrm{m}$ mitochondrial membrane potential was determined by FACS analysis using JC-1 (5,5',6,6'-tetrachloro-1,1',3,3'-tetraethylbenzimidazolylcarbocyanine iodide). For this purpose the Mitochondrial Membrane Potential Detection Kit (Stratagene, La Jolla, CA, USA) was used, as described in the manufacturer's instruction. $10^{6} \mathrm{HL}-60$ or HL-60/adr cells were treated for 1, 3, 6, 12 and $24 \mathrm{~h}$ with the tested drugs. After PBS washing, cells were incubated for $10 \mathrm{~min}$ in freshly prepared JC-1 solution $\left(10 \mathrm{mg} / \mathrm{ml}\right.$ in culture medium) at $37{ }^{\circ} \mathrm{C}$. Spare dye was removed by PBS washing and cellassociated fluorescence was measured with FACS.

\section{Statistical analysis}

If not stated otherwise, data are expressed as mean \pm SD. The results were analyzed using GraphPad Prism software. Statistical analyses were performed using t-test or two-way analysis of variance (ANOVA). To examine differences between the drug treatment responses, Bonferroni post-tests were conducted. $\mathrm{P}$ values below 0.05 were considered as statistically significant and marked with stars: ${ }^{*} \mathrm{p}<0.05$; $* * \mathrm{p}<0.01 ; * * * \mathrm{p}<0.001$.

\section{Results and Discussion}

At the first stage of our study, the sensitivity of HL60 leukemia cells and their drug-resistant sublines to the action of landomycin E (LE) and well-known anticancer drug doxorubicin (Dx) was studied in de- 
tail (Fig.1). It was revealed that overexpression of P-glycoprotein in HL-60/vinc cells increased their resistance profile to Dx 100-fold, while HL-60/adr cell line, overexpressing MRP-1, was found to be 200-fold more resistant to the Dx action compared to parental HL-60/wt line (Fig. 1). On [the] contrary, no difference in sensitivity of HL-60/wt, HL-60/adr and HL-60/vinc cells to [the] LE action was observed at $72 \mathrm{~h}$ drug incubation time, according to MTT tests (Fig.1).

Short-time drug toxicity experiments $(24 \mathrm{~h}$ incubation), analyzed by trypan blue exclusion test, have

\section{LE, 72h}

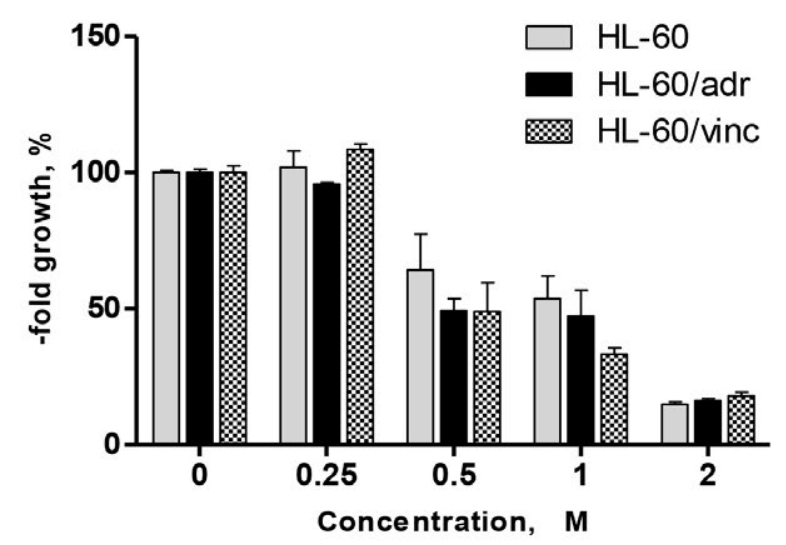

$\mathrm{Dx}, \mathbf{7 2 h}$

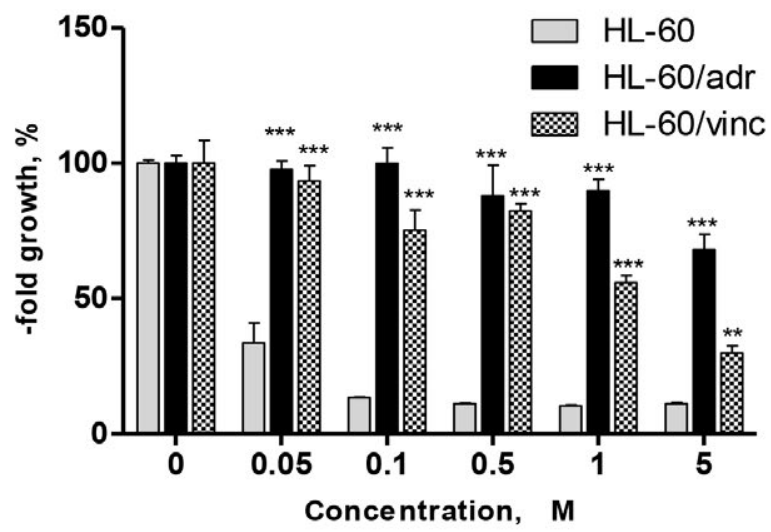

revealed similar tendencies - 20 -fold resistance increase of HL-60/vinc cell line, and 40-fold resistance increase of H1-60/adr cell line towards Dx (Fig.1), while for LE the only cells which showed a weak ( $\sim$-fold) decrease in sensitivity to this drug, were of HL-60/adr subline. Thus, the cytotoxic activity of $\mathrm{LE}$ is almost unaffected by ABC transporters, which makes it a promising compound for treatment of drug-resistant leukemia.

Previously we demonstrated that one of the landomycin family members - LA, possessing 6 sugar residues instead of 3 residues in LE, and thus higher
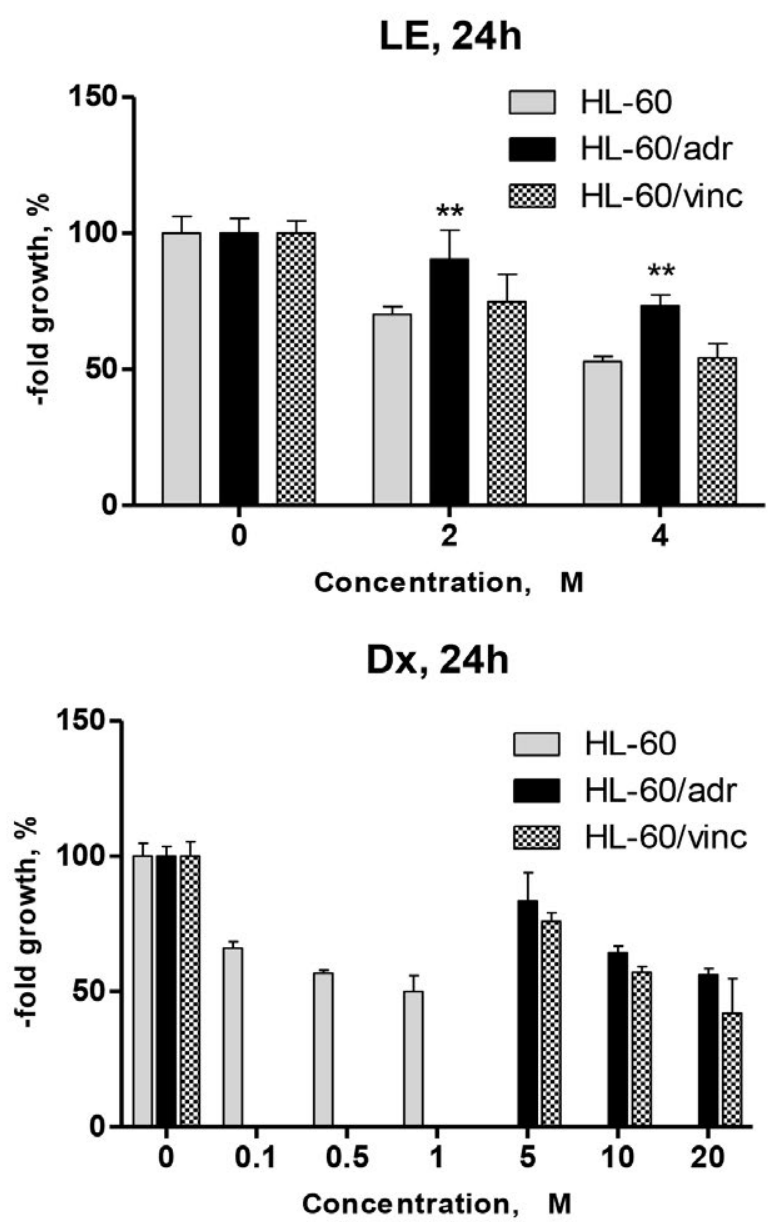

Fig. 1. Comparison of anticancer activities of LE and Dx towards human leukemia cells of HL-60 line and its drug-resistant sublines HL-60/adr (MRP-1+) and HL-60/vinc (P-gp+). Cell viability was analyzed by MTT assay after $72 \mathrm{~h}$ exposure to indicated concentrations of LE and Dx, or by trypan blue exclusion assay after $24 \mathrm{~h}$ exposure to aforementioned drugs. Graphs represent the mean $+/$ - SD of three independent experiments done in triplicates

** $\mathrm{p}<0.01, * * * \mathrm{p}<0.001$ relative to HL-60/wt cell line, 2-way ANOVA, Bonferroni post-test. 
cytotoxic activity, leads to specific two-phase ROS burst in Jurkat T-leukemia cells (Lehka et al, 2015), which consists of two peaks $1 \mathrm{~h}$ and $12 \mathrm{~h}$ after the target cell treatment with LA. Mitochondria, being the main energetic stations in the eukaryotic cells, are also considered to be the main source of ROS [15]. Thus, for the identification of nature and source of LE-induced ROS, the joint treatment of HL-60/adr/ vinc cells with LE and various ROS scavengers (N-acetylcysteine, sodium pyruvate) and mitochondrial respiratory chain inhibitors (antimycin A, oligomycin A, DPI) was addressed.

For studying potential impact of mitochondria on the cytotoxic activity of LE in vitro several specific inhibitors of mitochondrial respiratory chain were used, namely DPI (NADPH dehydrogenase inhibitor [16]), antimycin A (complex III inhibitor [17]) and oligomycin A (ATP-synthetase inhibitor [18]). However, it was revealed that all these compounds, except antimycin A ( $2 \mu \mathrm{M})$, are toxic to HL-60 leukemia cells, even in very low concentrations $(1 \mu \mathrm{M}$ for oligomycin A and $0.5 \mu \mathrm{M}$ for DPI) (Fig. 2). The same tendency was observed also for HL-60/adr cells, while HL-60/vinc cell line demonstrated a high internal resistance to the action of all tested mitochondrial inhibitors, thus indicating an insignificant role of mitochondria in the regulation of their proliferation and apoptosis. We did not observe any statistically significant impact of aforementioned compounds on inhibition or stimulation of LE cytotoxic action, mainly due to a high toxicity of oligomycin A and DPI towards the tested cell lines at $72 \mathrm{~h}$ incubation. However, in HL-60/vinc cell line, where no toxic activity of antimycin A, oligomycin A and DPI was observed, they possessed a little, still statistically insignificant impact on lowering antineoplastic action of LE. Thus, mitochondria seem to play rather secondary role in the LE-induced cell death.

For better understanding a role of specific ROS in LE-involved cell death, specific hydrogen peroxide scavenger sodium pyruvate [19] and wide-scale ROS scavenger N-acetylcysteine [20] were addressed. It was revealed that sodium pyruvate possessed the moderate cytoprotective activity towards the LE action $(\mathrm{P}<0.05$ for HL-60 cells and $\mathrm{P}<0.01$ for HL-60/adr cells), whereas NAC almost completely blocked its activity towards all tested cell lines $(\mathrm{P}<0.001)$. Such unexpectedly high efficiency of the NAC action may be explained not only by its ROS scavenging activity, but also by its indirect impact on the glutathione level in the cells [20].

Due to the fact that ROS are short-living molecules, MTT assays for $72 \mathrm{~h}$ drug incubation and trypan blue tests for $24 \mathrm{~h}$ drug treatment may not show all the dynamics of cellular processes, taking place immediately after drug entry into the cells. For better understanding a role of specific ROS and mitochondria at early timepoints of LE action, a level of hydrogen peroxide in the cells was measured by flow cytometry using DCFDA dye at $1,3,6,12,24 \mathrm{~h}$ after LE addition to studied cell lines. As seen in Fig. 3-5, LE leads to the] appearance of typical two-peak $\mathrm{H}_{2} \mathrm{O}_{2}$ burst in wild-type HL-60 cells, like previously observed by us in LA in Jurkat T-cells (Lehka et al, 2015). At the beginning (1h) the ROS level increases 3-fold (for $2 \mu \mathrm{M}$ dose of LE) or 5.5-fold (for $4 \mu \mathrm{M}$ LE), and this process is partially inhibited by $\mathrm{N}$-acetylcysteine (see Fig. 3)

Then at $3 \mathrm{~h}$ the ROS level under LE treatment rapidly drops, almost reaching a control level at $6 \mathrm{~h}$, and then slowly recovers at $12 \mathrm{~h}$, slightly decreasing again at $24 \mathrm{~h}$ (Fig. 3). Mitochondrial respiratory chain inhibitors DPI and oligomycin A have no statistically significant impact on the LE-derived ROS production, as seen in Fig. 3, thus confirming our previous MTT data (see Fig.2).

However, in the HL-60/adr cell line, which was found 2-fold more resistant to the LE action, the drug leads to a massive ROS production, which is approximately 2-fold higher compared to HL-60/wt cells (Fig. 4), and NAC strongly reduces it almost to a control level. Surprisingly, the ROS level under LE treatment in HL-60/adr cells does not drop as rapidly as observed in parental HL-60 line (Fig.4). Instead, it slowly decreases from $1 \mathrm{~h}$ till $24 \mathrm{~h}$, so no a "paradox" double peak is observed here. Despite major $\mathrm{H}_{2} \mathrm{O}_{2}$ production, neither DPI, nor oligomycin A have significant impact on the ROS production 


\section{HL-60}

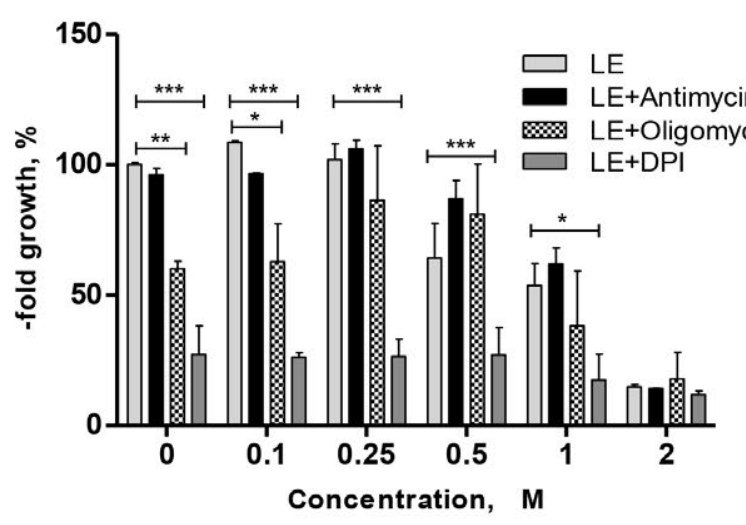

HL-60/adr
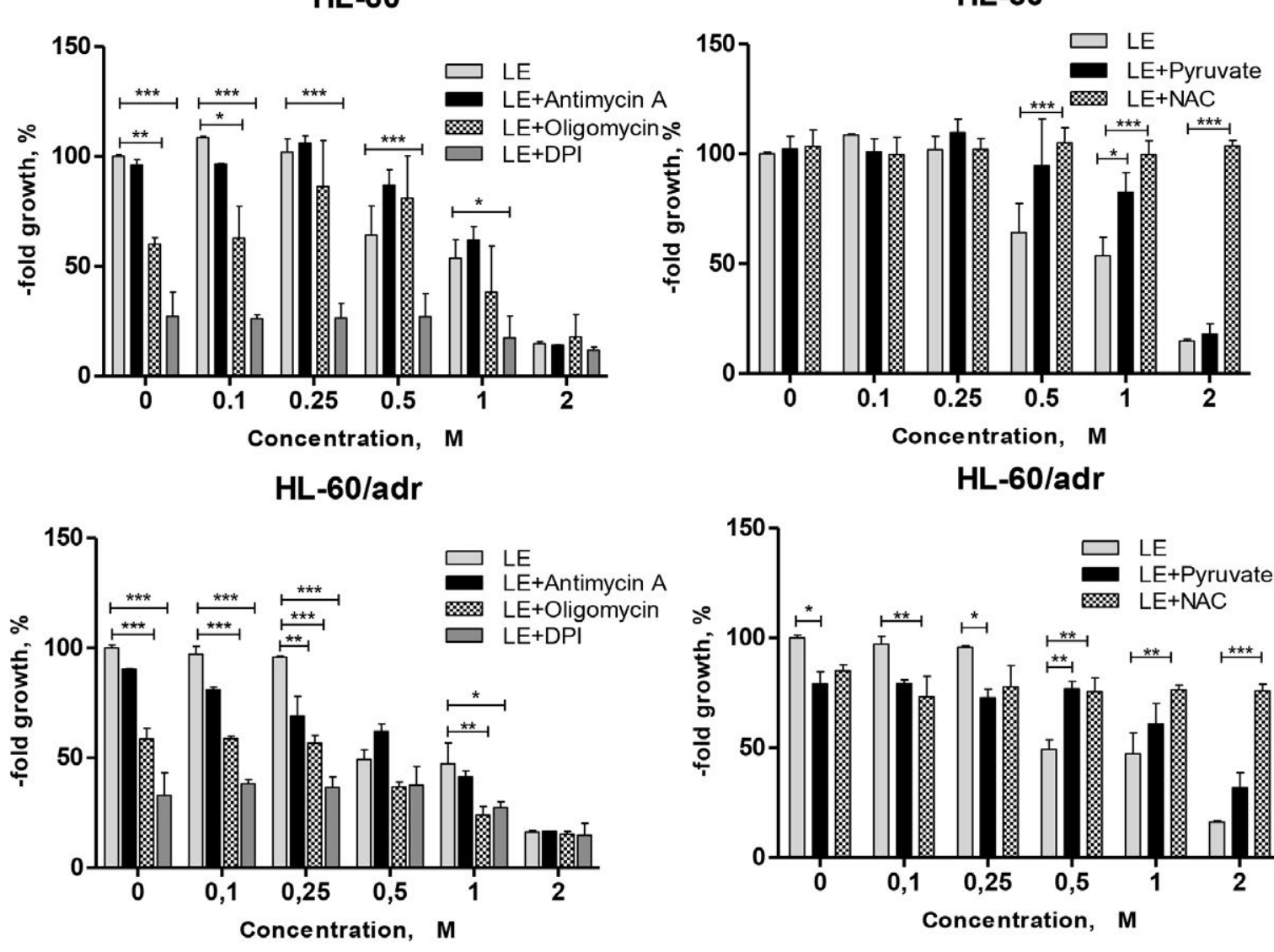

HL-60/adr

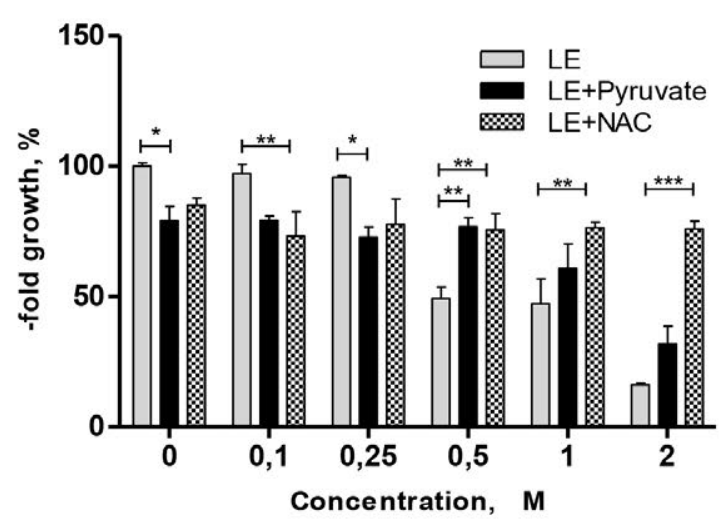

HL-60/vinc
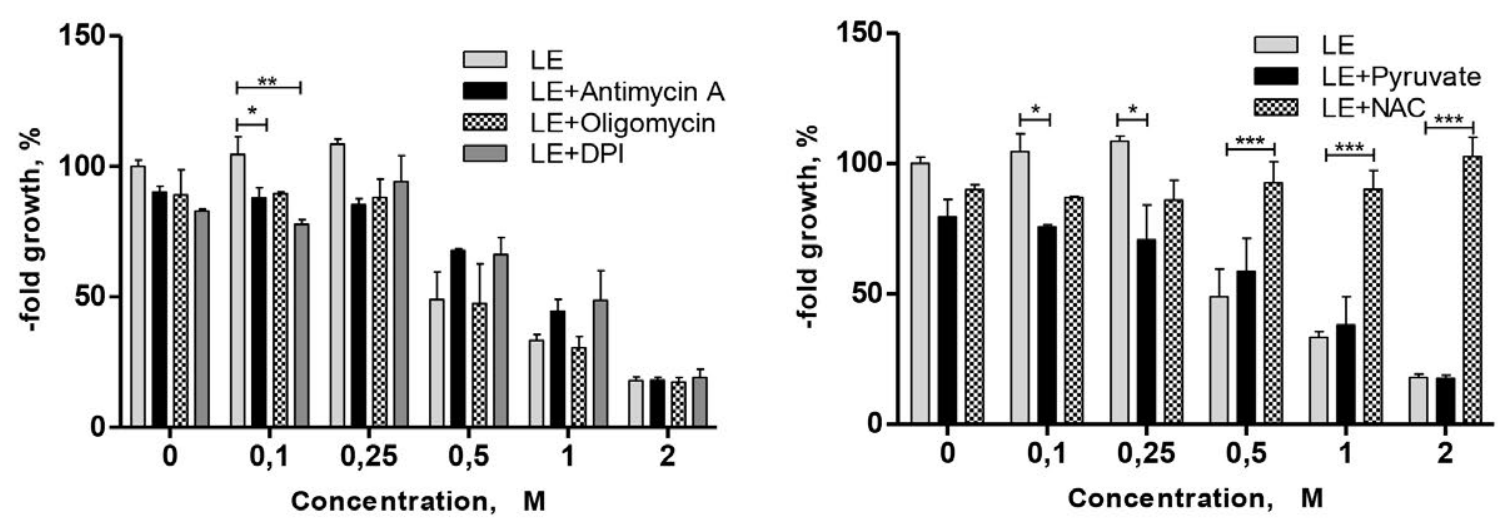

Fig. 2. Study of modulating effect of mitochondrial respiratory chain inhibitors on cytotoxic activities of LE towards human leukemia cells of HL-60 line and its drug-resistant sublines HL-60/adr (MRP-1+) and HL-60/vinc (P-gp+). Cell viability was analyzed by MTT assay after $72 \mathrm{~h}$ exposure to indicated concentrations of LE. Graphs represent the mean $+/$ - SD of three independent experiments done in triplicates

$* \mathrm{p}<0.05, * * \mathrm{p}<0.01, * * * \mathrm{p}<0.001$ relative to LE, 2-way ANOVA, Bonferroni post-test. DPI - diphenylene iodonium, NAC - N-acetylcyteine, Pyruvate - sodium pyruvate 
HL-60, 1h

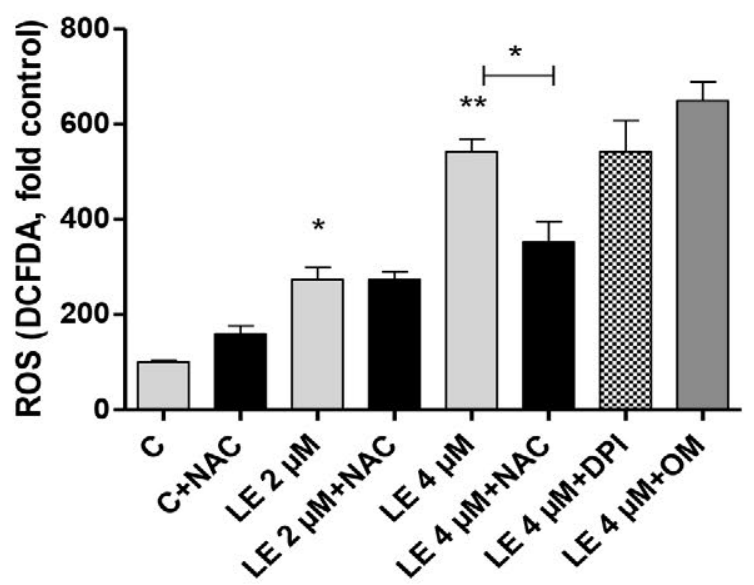

HL-60, 6h

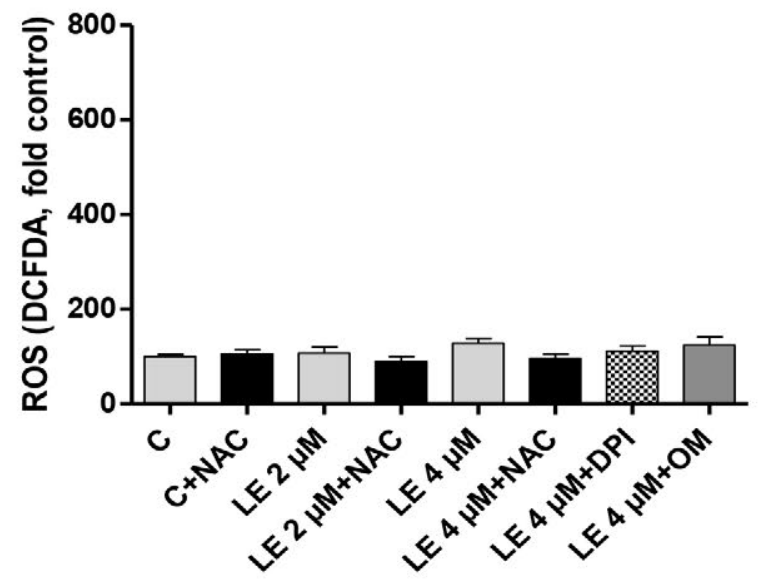

HL-60,24h

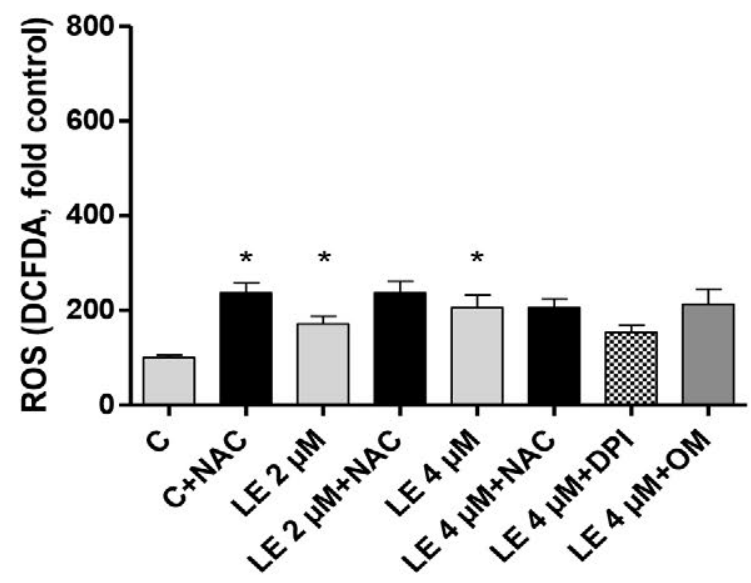

HL-60. 3h

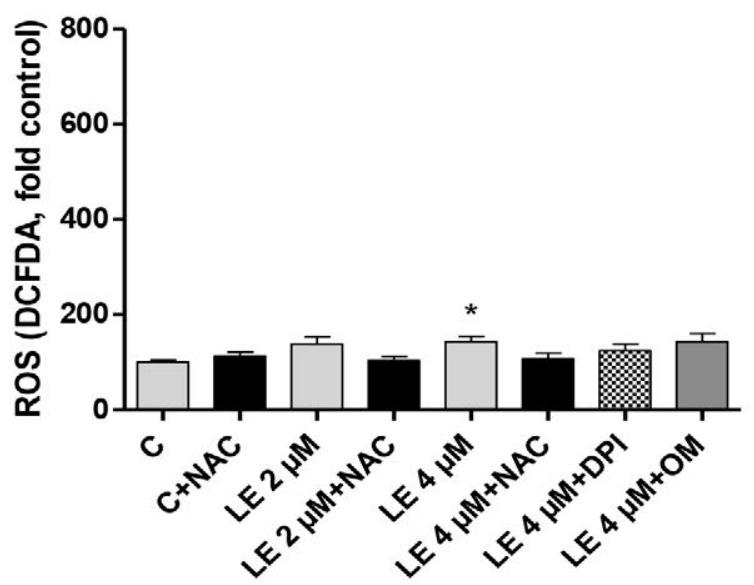

HL-60,12h

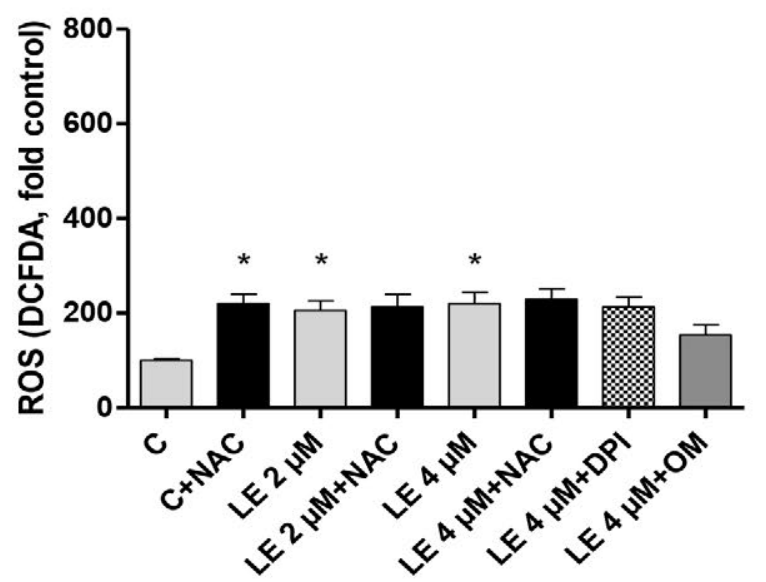

Fig. 3. LE leads to significant increase of hydrogen peroxide level in human leukemia cells of HL-60 line already at $1 \mathrm{~h}$ after addition to cell culture, which is partially inhibited by N-acetylsysteine, but not by mitochondrial respiratory chain inhibitors DPI and oligomycin A. The cells were pre-treated for $30 \mathrm{~min}$ with NAC, DPI and OM then treated with either vehicle, LE $(2 \mu \mathrm{M}$ and $4 \mu \mathrm{M})$ and then stained with DCFDA for analysis by flow cytometry. Bar graphs show an increase (over vehicle control) in the percentage of cells with positive DCF fluorescence in each sample. Baseline level of hydrogen peroxide in control cells is taken as $100 \%$.

DPI - diphenylene iodonium, NAC - N-acetylcyteine, OM oligomycin $\mathrm{A}$

$* \mathrm{p}<0.05, * * \mathrm{p}<0.01$ relative to control, unpaired t-test. $\mathrm{p}<0.05$, relative to $\mathrm{LE}$, unpaired $\mathrm{t}$-test. 
HL-60/adr, 1h
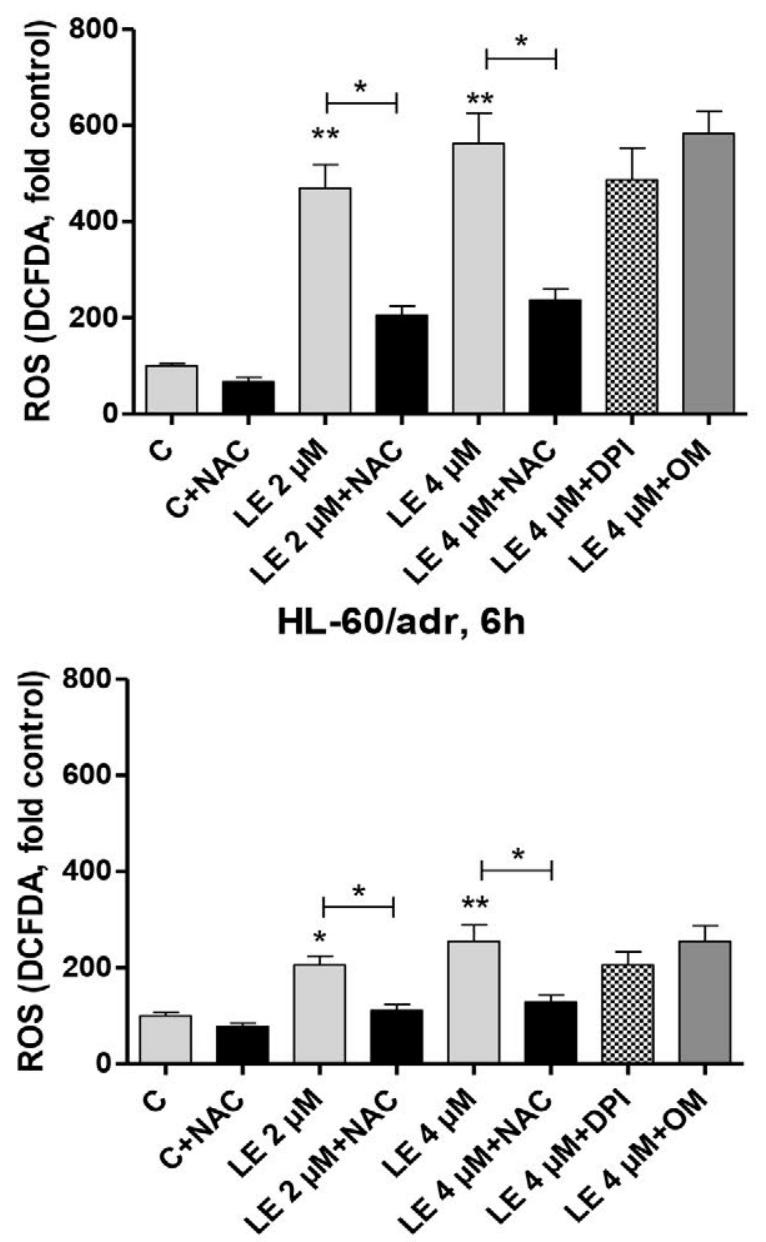

HL-60/adr, 24h



HL-60/adr, 3h

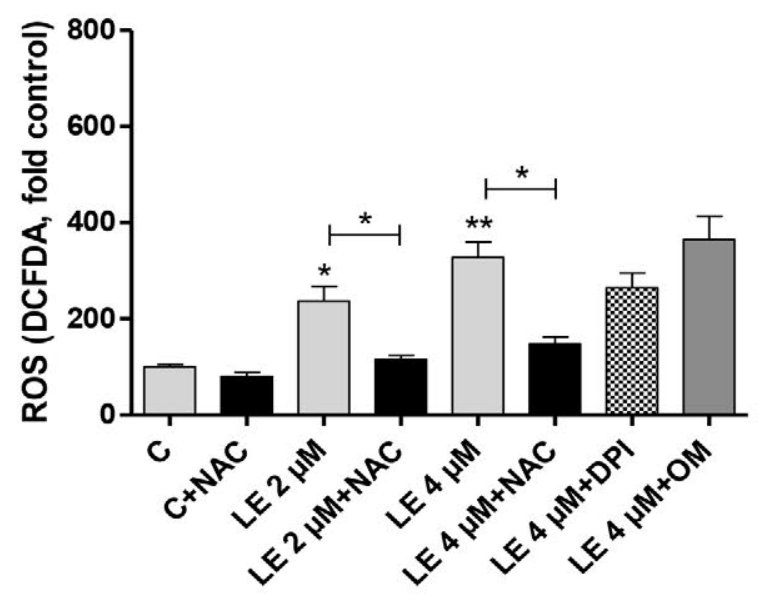

HL-60/adr, 12h



Fig. 4. LE leads to over 2-fold increase of hydrogen peroxide level in human leukemia cells of HL-60/adr line, overexpressing MRP-1, in comparison to HL-60 parental line already at $1 \mathrm{~h}$ after addition to cell culture, which is strongly inhibited by N-acetylsysteine, but not by mitochondrial respiratory chain inhibitors DPI and oligomycin A. Cells were pre-treated for 30 min with NAC, DPI and OM, then treated with either vehicle, LE $(2 \mu \mathrm{M}$ and $4 \mu \mathrm{M}$ ) and then stained with DCFDA for analysis by flow cytometry. Bar graphs show an increase (over a vehicle control) in the percentage of cells with positive DCF fluorescence in each sample. A baseline level of hydrogen peroxide in control cells is taken as $100 \%$.

DPI - diphenylene iodonium, NAC - N-acetylcyteine, OM oligomycin A

$* \mathrm{p}<0.05, * * \mathrm{p}<0.01$ relative to control, unpaired $\mathrm{t}$-test. $\mathrm{p}<0.05$, relative to LE, unpaired t-test. 


\section{HL-60/vinc, $1 \mathrm{~h}$}
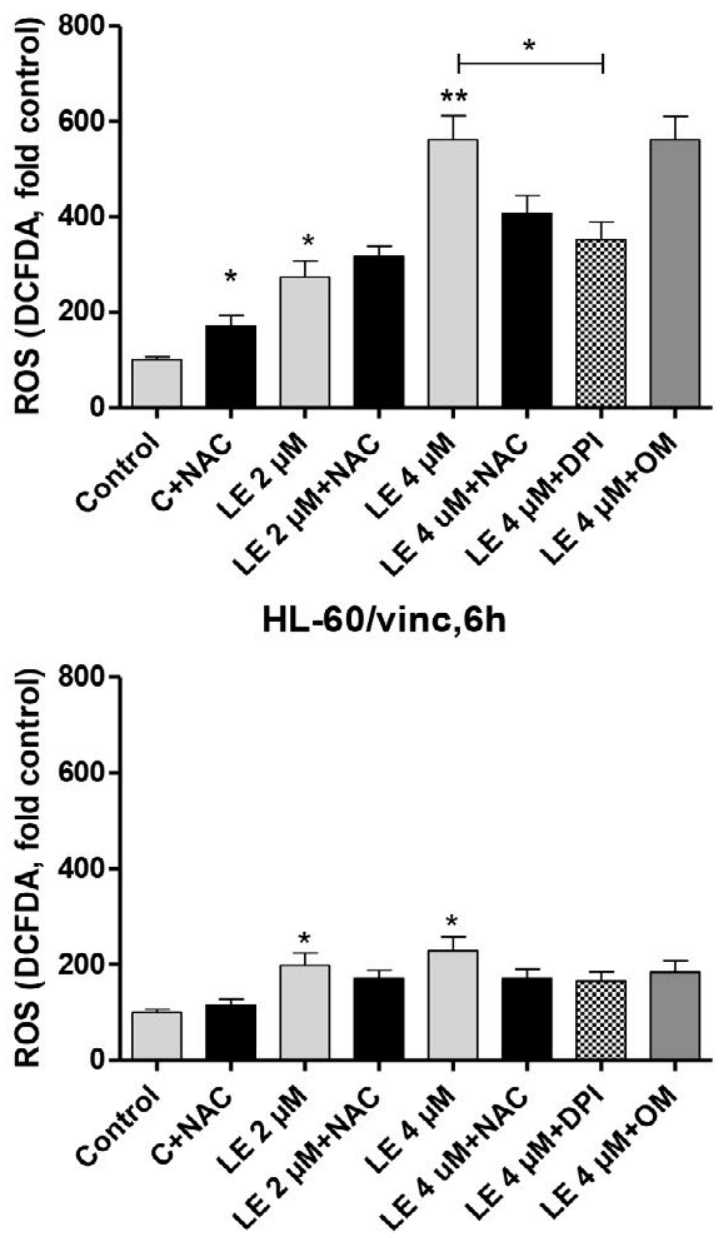

HL-60/vinc,24h

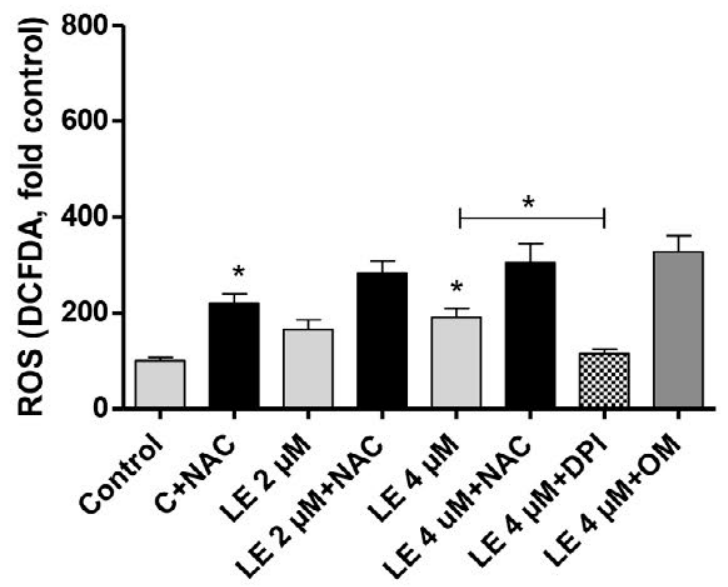

\section{HL-60/vinc, $3 \mathrm{~h}$}

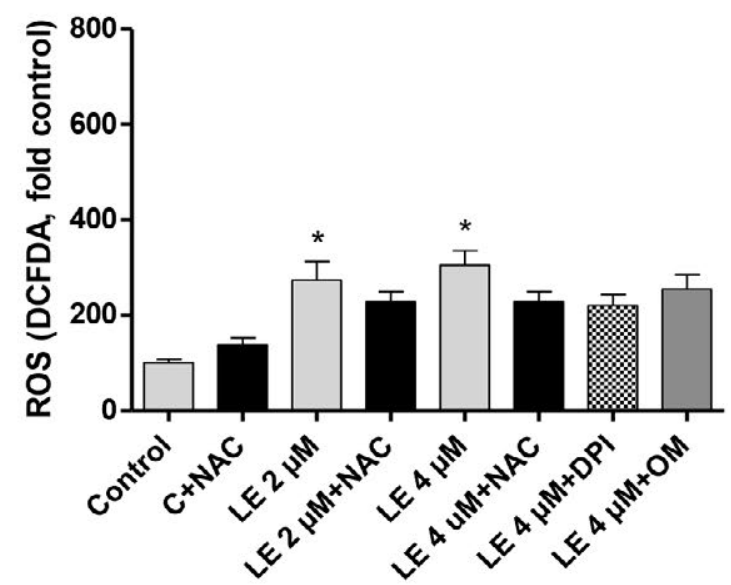

HL-60/vinc, $12 \mathrm{~h}$

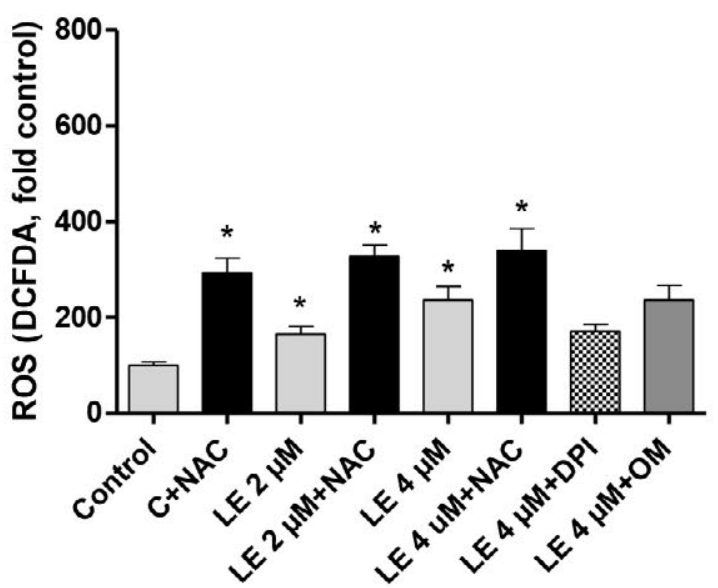

Fig. 5. No major differences in ROS production under LE action between P-gp overexpressing HL-60/vinc cell line and HL-60 parental cells are observed. NADPH oxidase inhibitor DPI partially decreases LE-driven ROS at $24 \mathrm{~h}$ cells incubation with the drug. Cells were pre-treated for $30 \mathrm{~min}$ with NAC, DPI and OM, then treated with either vehicle, $\operatorname{LE}(2 \mu \mathrm{M}$ and $4 \mu \mathrm{M})$ and then stained with DCFDA for analysis by flow cytometry. Bar graphs show an increase (over vehicle control) in the percentage of cells with positive DCF fluorescence in each sample. Baseline level of hydrogen peroxide in control cells is taken as $100 \%$.

DPI - diphenylene iodonium, NAC - N-acetylcyteine, OM oligomycin A

$* \mathrm{p}<0.05, * * \mathrm{p}<0.01$ relative to control, unpaired t-test. $\mathrm{p}<0.05$, relative to LE, unpaired t-test. 
under the LE action, thus indicatin their weak involvement in this process (Fig. 4).

The only slight ROS-inhibitive effect of DPI towards the LE action was observed in the HL-60/vinc cell line, characterized by P-gp overexpression (Fig. 5). However, it was much lower compared to NAC alone and statistically insignificant. Thus, all studied mitochondrial respiratory chain inhibitors have a slight effect on the LE-induced ROS produc-

$A$

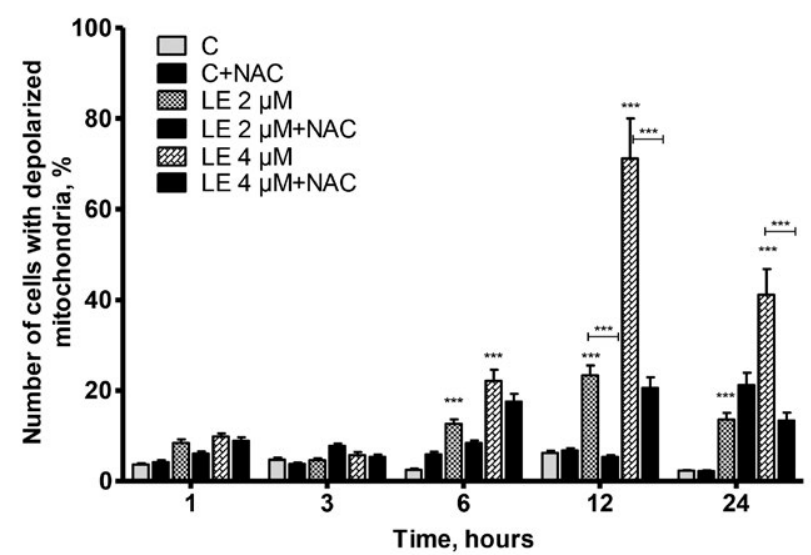

$C$

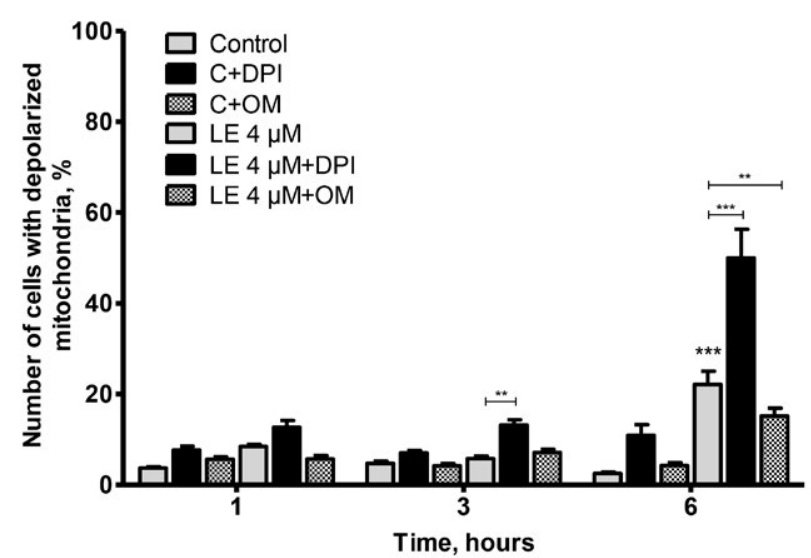

tion, which may indicate the fact that LE leads to the extra mitochondrial ROS production.

For checking this hypothesis, the status of mitochondrial membrane in HL-60/wt and HL-60/adr cells was tested using JC-1 staining. Unfortunately, JC-1, being a mitochondrial stain, was also found by us to be a perfect substrate for P-glycoprotein, thus the measurement of JC-1 fluorescence in HL-60/ vinc cells was technically impossible due to a mas-

$\boldsymbol{B}$

HL-60/adr

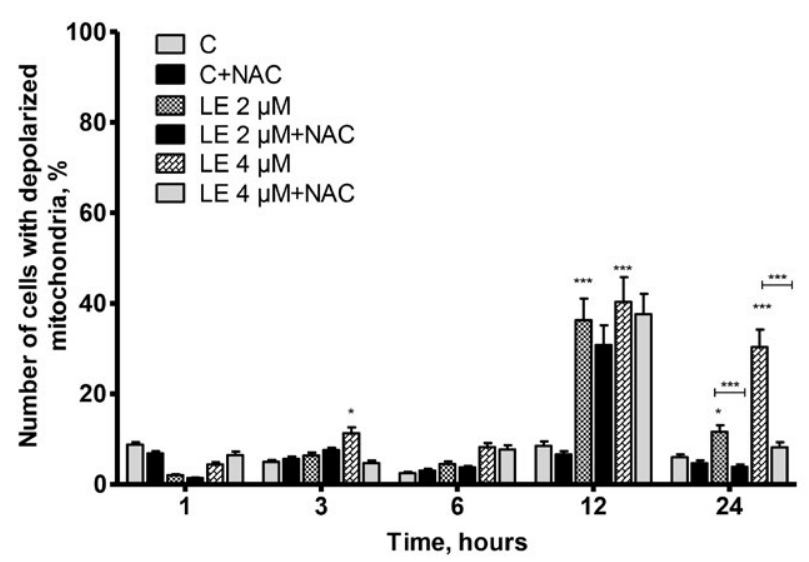

D

HL-60/adr

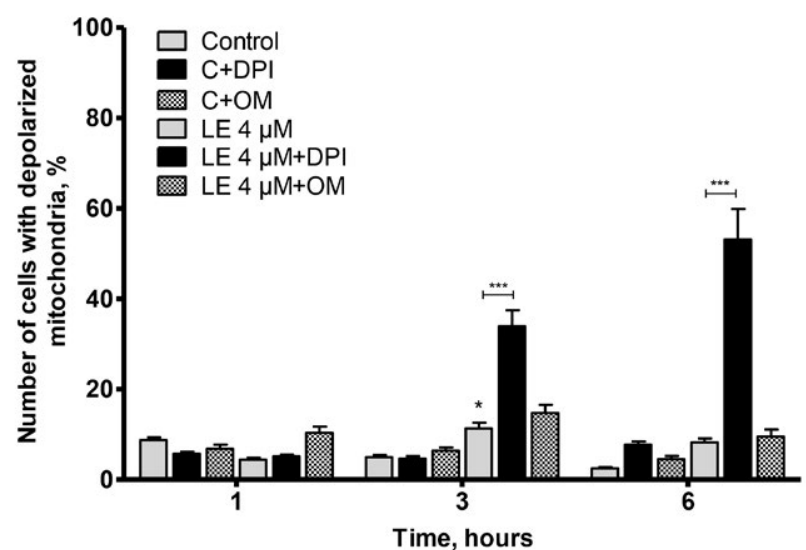

Fig.6. LE leads to late depolarization of mitochondrial membrane in HL-60 and HL-60/adr cells, which takes place mainly at $12 \mathrm{~h}$ after incubation with the drug. DPI possesses strong synergistic effect with LE on depolarization of mitochondria, but this effect is also observed much later (6h) than massive ROS burst at $1 \mathrm{~h}$ under LE treatment. Cells were pre-treated for 30 min with NAC, Oligomycin A or DPI, then treated with either vehicle, LE $(2 \mu \mathrm{M}$ and $4 \mu \mathrm{M})$ and then stained with JC-1. Intracellular JC-1 fluorescence was measured by FACS and analyzed by Cytomation Summit software. 
sive dye extrusion from the cells. As seen in Fig. 6, LE leads to the late depolarization of mitochondria in HL-60 and HL-60/adr cells, reaching its maximum at $12 \mathrm{~h}$ timepoint - time, which coincides with the second ROS burst observed under the LE action (see Fig.3). However, no signs of mitochondria depolarization were observed at $1 \mathrm{~h}$ timepoint in both cell lines, where the major ROS peak was observed by us (Fig. 3-5). This fact further indicates a secondary role of mitochondria in the LE-induced ROS production, and corresponds to the second ROS burst, but not the first one (1h). At a combination of LE and mitochondrial respiratory chain inhibitors it was revealed that ATP-synthase inhibitor oligomycin A had no statistically significant impact on the LE-induced mitochondrial membrane depolarization at $1 \mathrm{~h}, 3 \mathrm{~h}$ and $6 \mathrm{~h}$ timepoints, whereas DPI strongly enhanced the LE-induced mitochondrial membrane depolarization, increasing it 2.5-5-fold depending on drug concentration and incubation time (Fig. 6). It is known that DPI, blocking mitochondrial Complex I, can lead to subsequent oxidative stress in the cells [16]. The synergistic action of DPI and LE at $6 \mathrm{~h}$ timepoint on depolarization of mitochondria (Fig. 6) clearly indicates that both compounds induce the mitochondrial-mediated ROS production. It takes place much later (12h) compared to a massive ROS burst, caused by LE in both sensitive, and even higher, -in doxorubicin-resistant HL-60 cells at $1 \mathrm{~h}$. As DPI was shown to be a broad NAPDH oxidase inhibitor, blocking activity not only of Complex I, but also of other membrane-bound NADPH-oxidases [16], the LE-induced an early ROS burst cannot be explained by involvement of either mitochondria or of the plasma membrane ROS-producing enzymes. The only possible explanation of this early ROS burst is the hydrogen peroxide production by drug itself during its entry into the target cell. It has been already shown that all compounds containing quinone motif in their structure, may be the source of ROS itself as the catalyzers of the continuous redox cycles [21]. These ROS may be inhibited by cellular antioxidant systems, and glutathione system is considered to be one of the most efficient [22].
The GSH level in HL-60/adr cells was shown to be 2-fold lower in comparison to HL-60/wt cells [23]. This may explain the nature of a 2-fold higher ROS burst, induced by LE in HL-60/adr cells, as this antioxidant at a lower level inside the cells is unable to quickly scavenge all hydrogen peroxide, produced by LE.

Several studies have already demonstrated a tight connection between MRP-1 pump and intracellular GSH pool, which plays an important role in the functioning of this drug transporter [24]. In particular, GSH depletion by buthionine sulphoximine (BSO) increases the accumulation of DNR and Rhodamine 123 (Rh123) in several MRP1-positive cell lines [25], thus partially reverting their resistance to these drugs.

The observed connection between the glutathione antioxidant system and the MRP-1 expression in HL-60/adr cells may explain their higher resistance profile to LE. HL-60/vinc cells, which have the basal GSH level, do not demonstrate any significant resistance to the LE action, even despite P-gp overexpression. Thus, joint targeting of tumor cells by LE together with GSH-depleting compounds (such as $\mathrm{BSO}$ ) may be a promising approach in the treatment of drug-resistant tumors.

\section{Conclusions}

LE effectively circumvents drug resistance of HL-60 leukemia cells in vitro, caused by P-gp overexpression, whereas in HL-60/adr cells, characterized by MRP-1 overexpression, the activity of this drug drops 2-fold compared to the parental cell line. The LEinduced cell death is accompanied by a massive ROS burst, consisting of two peaks of hydrogen peroxide production - major one at $1 \mathrm{~h}$ and secondary at $12 \mathrm{~h}$ after drug treatment. The highest ROS production was observed in HL-60/adr cells, which have shown 2-fold increase of resistance to LE compared to the parental cells. However, mitochondria seem to be involved only at tetherminal stages of LE-induced apoptosis (12h), indicating the extra-mitochondrial ROS production by LE at early timepoints. The mitochondrial respiratory chain inhibitors failed to inhibit the LEinduced ROS burst at both early and terminal stages of the LE-induced cell death, and only one of them (DPI) 
was shown to have synergistic effect with LE on the mitochondrial membrane depolarization at $6 \mathrm{~h}$ of cell incubation with the drug. All these data indicate that there was no involvement of mitochondria at early stages of the LE action, which are accompanied by ROS burst, possibly produced by the drug itself due to its specific chemical structure. A low glutathione level in HL-60/adr cells, which is a well-known antioxidant, may explain a 2-fold higher ROS burst, observed under the cytotoxic action of LE towards these cells.

\section{Funding}

This work was partially supported by bilateral UkraineAustria grants for 2011-2014 years; Grant of President of Ukraine Gp/F32/192-2011; CRDF Global Grant \# FSCX-14-60609-0; Ministry of Science and Education of Ukraine grant \#M/122-2015; grants of WestUkrainian Biomedical Research Center (WUBMRC) in 2008-2016, given to R. Panchuk and L. Lehka

\section{REFERENCES}

1. Gottesman MM, Fojo T, Bates SE. Multidrug resistance in cancer: role of ATP-dependent transporters. Nat Rev Cancer. 2002;2(1):48-58.

2. Young $R C$. Drug resistance: the clinical problem. Cancer Treat Res. 1989;48:1-12.

3. Ford JM, Hait WN. Pharmacology of drugs that alter multidrug resistance in cancer. Pharmacol Rev. 1990;42(3):155-99.

4. Jamroziak K, Robak T. Pharmacogenomics of MDR1/ $\mathrm{ABCB} 1$ gene: the influence on risk and clinical outcome of haematological malignancies. Hematology. 2004;9(2): 91-105.

5. Leighton JC Jr, Goldstein LJ. P-glycoprotein in adult solid tumors. Expression and prognostic significance. Hematol Oncol Clin North Am. 1995;9(2):251-73.

6. Eberl S, Renner B, Neubert A, Reisig M, Bachmakov I, König J, Dörje F, Mürdter TE, Ackermann A, Dormann H, Gassmann KG, Hahn EG, Zierhut S, Brune K, Fromm MF. Role of p-glycoprotein inhibition for drug interactions: evidence from in vitro and pharmacoepidemiological studies. Clin Pharmacokinet. 2007;46(12):1039-49.

7. Munoz M, Henderson M, Haber M, Norris M. Role of the MRP1/ABCC1 multidrug transporter protein in cancer. IUBMB Life. 2007;59(12):752-7.

8. Kodaira H, Kusuhara H, Ushiki J, Fuse E, Sugiyama Y. Kinetic analysis of the cooperation of P-glycoprotein (P-gp/ Abcb1) and breast cancer resistance protein (Bcrp/Abcg2) in limiting the brain and testis penetration of erlotinib, fla- vopiridol, and mitoxantrone. J Pharmacol Exp Ther. 2010; 333(3):788-96.

9. Henkel T, Rohr J, Beale JM, Schwenen L. Landomycins, new angucycline antibiotics from Streptomyces sp. I. Structural studies on landomycins A-D. J Antibiot (Tokyo). 1990; 43(5):492-503.

10. Luzhetskyy A, Zhu L, Gibson M, Fedoryshyn M, Dürr $C$, Hofmann $C$, Hoffmeister D, Ostash B, Mattingly $C$, Adams V, Fedorenko V, Rohr J, Bechthold A. Generation of novel landomycins $\mathrm{M}$ and $\mathrm{O}$ through targeted gene disruption. Chembiochem. 2005;6(4):675-8.

11. Shaaban KA, Srinivasan S, Kumar R, Damodaran C, Rohr J. Landomycins P-W, cytotoxic angucyclines from Streptomyces cyanogenus S-136. J Nat Prod. 2011;74(1):2-11.

12. Panchuk R, Korynevska A, Ostash B, Osyp Y, Fedorenko V, Stoika R. Study of mechanisms of landomycin E action on mammalian cells. Visn L'viv Univ Ser Biol. 2004; 35:54-9.

13. Korynevska A, Heffeter P, Matselyukh B, Elbling L, Micksche $M$, Stoika R, Berger W. Mechanisms underlying the anticancer activities of the angucycline landomycin E. Biochem Pharmacol. 2007;74(12):1713-26.

14. Lehka LV, Panchuk RR, Berger W, Rohr J, Stoika RS. The role of reactive oxygen species in tumor cells apoptosis induced by landomycin A. Ukr Biochem J. 2015;87(5):72-82.

15. Dröse $S$, Brandt $U$. Molecular mechanisms of superoxide production by the mitochondrial respiratory chain. Adv Exp Med Biol. 2012;748:145-69.

16. Riganti C, Gazzano E, Polimeni M, Costamagna C, Bosia A, Ghigo D. Diphenyleneiodonium inhibits the cell redox metabolism and induces oxidative stress. J Biol Chem. 2004;279(46):47726-31.

17. Chen Q, Vazquez EJ, Moghaddas S, Hoppel CL, Lesnefsky EJ. Production of reactive oxygen species by mitochondria: central role of complex III. J Biol Chem. 2003; 278(38):36027-31.

18. Shchepina LA, Pletjushkina OY, Avetisyan AV, Bakeeva LE, Fetisova EK, Izyumov DS, Saprunova VB, Vyssokikh MY, Chernyak BV, Skulachev VP. Oligomycin, inhibitor of the F0 part of H+-ATP-synthase, suppresses the TNF-induced apoptosis. Oncogene. 2002;21(53):8149-57.

19. Jagtap JC, Chandele A, Chopde BA, Shastry P. Sodium pyruvate protects against $\mathrm{H}(2) \mathrm{O}(2)$ mediated apoptosis in human neuroblastoma cell line-SK-N-MC. J Chem Neuroanat. 2003;26(2):109-18.

20. Samuni Y, Goldstein S, Dean OM, Berk M. The chemistry and biological activities of $\mathrm{N}$-acetylcysteine. Biochim Biophys Acta. 2013;1830(8):4117-29.

21. Minotti G, Menna P, Salvatorelli E, Cairo G, Gianni L. Anthracyclines: molecular advances and pharmacologic developments in antitumor activity and cardiotoxicity. Pharmacol Rev. 2004;56(2):185-229.

22. Liou GY, Storz P. Reactive oxygen species in cancer. Free Radic Res. 2010;44(5):479-96. 
23. Lutzky J, Astor MB, Taub RN, Baker MA, Bhalla K, Gervasoni JE Jr, Rosado M, Stewart V, Krishna S, Hindenburg AA. Role of glutathione and dependent enzymes in anthracyclineresistant HL60/AR cells. Cancer Res. 1989;49(15):4120-5.

24. Legrand O, Simonin G, Beauchamp-Nicoud A, Zittoun R, Marie JP. Simultaneous activity of MRP1 and Pgp is correlated with in vitro resistance to daunorubicin and with in vivo resistance in adult acute myeloid leukemia. Blood. 1999;94(3):1046-56.

24. Legrand $O$, Zittoun R, Marie JP. Role of MRP1 in multidrug resistance in acute myeloid leukemia. Leukemia. 1999;13(4):578-84.

25. Versantvoort $C H$, Broxterman HJ, Bagrij T, Scheper RJ, Twentyman PR. Regulation by glutathione of drug transport in multidrug-resistant human lung tumour cell lines overexpressing multidrug resistance-associated protein. Br J Cancer. 1995;72(1):82-9.

\section{Мітохондрії не відіграють основної ролі в індукції оксидативного стресу при доланні множинної лікарської стійкості в лейкозних клітинах лінії HL-60 ландоміцином E}

\section{Р. Р. Панчук, Л. В. Легка, Ю. Рор, В. Бергер, Р. С. Стойка}

Мета. Молекулярні механізми участі активних форм кисню (АФК) в доланні множинної лікарської стійкості злоякісних клітин новим ангуцикліновим антибіотиком ландоміцином Е в лейкозних клітинах людини лінії HL-60 і іï сублініях HL-60/adr i HL-60/vinc, резистетних до хіміотерапії. Методи. МТT тест, тест на життєздатність клітин з трипановим синім, фарбування клітин флуоресцентними барвниками DCFDA i JC-1. Результати. Ландоміцин Е (ЛЕ) призводить до значного зростання продукції пероксиду водню в клітинах лінії HL-60 вже на 1 год після додавання препарату до культури клітин, в той час як деполяризация мітохондрій спостерігаються тільки на 6-12 год, що вказує на позамітохондріальне джерело АФК за дії цього антибіотика. Клітини лінії HL-60/vinc (Р-глікопротеїн +), незважаючи на 100-кратне зростання стійкості до доксорубіцину (Dx), продемонстрували ідентичну чутливість до ЛЕ в порівнянні з вихідною клітинною лінією, в той час як клітини лінії HL-60/adr (MRP- 1+), які проявляли 200-кратне зростання стійкості до дії Dx, показали слабке (в 2 рази) зниження чутливості до ЛЕ. Долання стійкості до ліків ландоміцином Е у клітинах лінії HL-60/adr супроводжувалося 2-кратним зростанням рівня $\mathrm{H}_{2} \mathrm{O}_{2}$ в порівнянні $з$ клітинами дикого типу, але мітохондріальні інгібітори дихального ланцюга не проявляли ніякого впливу на це явище. Висновки. ЛЕ-індукована загибель пухлинних клітин супроводжується масовим виробництвом перекису водню, що складається 3 двох піків - основного (1 год) і вторинного (на 12 год дії препарату). Найвища продукція АФК спостерігалася в клітинах лінії HL-60/adr, які показали 2-кратне збільшення стійкості до ЛЕ в порівнянні з вихідною лінією HL-60. Мітохондрії, очевидно, відіграють вторинну роль в цьому процесі, оскільки використання специфічних інгібіторів дихального ланцюга мітохондрій ніяк не вплинуло на ранню індукцію АФК за дії ЛЕ в пухлинних клітинах.

Кл юч о в і с с о в а: ландоміцин E, ROS, мітохондрії, стійкість пухлин до ліків, апоптоз

\section{Митохондрии не играют основной роли в индукции оксидативного стресса при преодолении множественной лекарственной устойчивости в лейкозных клетках линии HL-60 ландомицином E}

\section{Р. Р. Панчук, Л. В. Легкая, Ю. Рор, В. Бергер, Р. С. Стойка}

Цель. Молекулярные механизмы участия активных форм кислорода (АФК) в преодолении множественной лекарственной устойчивости злокачественных клеток новым ангуциклиновым антибиотиком ландомицином Е в лейкозных клетках человека линии HL-60 и ее сублиниях HL-60/adr и HL-60/vinc, резистентных к химиотерапии. Методы. MTT тест, тест на жизнеспособность клеток с трипановым синим, окраска клеток флуоресцентными красителями DCFDA и JC-1. Результаты. Ландомицин Е (ЛЕ) приводит к значительному росту продукции пероксида водорода в клетках линии HL-60 уже на 1 ч после добавления препарата к культуре клеток, в то время как деполяризация митохондрий наблюдаются только на 6-12 ч, что указывает на внемитохондриальный источник АФК происхождения при действии этого антибиотика. Клетки линии HL-60 vinc (Р-гликопротеин+), несмотря на 100-кратный рост устойчивости к доксорубицину (Dx), продемонстрировали идентичную чувствительность к ЛЕ по сравнению с исходной клеточной линией, в то время как клетки линии HL-60/adr (MRP-1+), которые проявляли 200-кратный рост устойчивости к действию Dx, показали слабое (в 2 раза) снижение чувствительности к ЛЕ. Преодоление устойчивости к лекарствам ландомицином Е в клетках линии HL-60/adr сопровождалось 2-кратным ростом уровня $\mathrm{H}_{2} \mathrm{O}_{2}$ по сравнению с клетками дикого типа, но митохондриальные ингибиторы дыхательной цепи не проявляли никакого влияния на это явление. Выводы. ЛЕиндуцированная гибель опухолевых клеток сопровождается массовым производством перекиси водорода, состоящей из двух пиков - основного (1 час) и вторичного (на 12 ч действия препарата). Самая высокая продукция АФК наблюдалась в клетках линии HL-60/adr, которые показали 2-кратное увеличение устойчивости к ЛЕ по сравнению с исходной линией HL-60. Митохондрии, очевидно, играют вторичную роль в этом процессе, поскольку использование специфических ингибиторов митохондриальной дыхательной цепи никак не повлияло на раннюю индукцию АФК при действии ЛЕ на опухолевые клетки.

Ключевы е слова: ландомицин E, ROS, митохондрии, устойчивость опухолей к лекарствам, апоптоз

Received 21.02.2016 